\title{
Scholarly Persona Formation and Cultural Ambassadorship: Female Graduate Students Travelling Between Belgium and the United States
}

Kaat Wils and Pieter Huistra

In February 1923, the Brussels physicist and secondary school teacher Alice Scouvart contacted one of the American staff members of the Commission for Relief in Belgium (CRB) Educational Foundation in Brussels to recommend a candidate for a fellowship for a year of graduate study in the United States. A former fellow herself, Scouvart had good contacts with staff member Millard Shaler. She explained that the candidate, Elisabeth Pissoort, doctor in medicine, had been a student of

\author{
K. Wils $(\bowtie)$ \\ KU Leuven, Leuven, Belgium \\ e-mail: kaat.wils@kuleuven.be \\ P. Huistra \\ Utrecht University, Utrecht, The Netherlands \\ e-mail: p.a.huistra@uu.nl \\ (C) The Author(s) 2021 \\ K. Niskanen and M. J. Barany (eds.), Gender, Embodiment, \\ and the History of the Scholarly Persona, \\ https://doi.org/10.1007/978-3-030-49606-7_4
}


hers, "perfect on account of school work, behavior and power of will". Scouvart continued in her less-than-perfect English:

I think that Miss Pissoort is especially interesting because she is an orphan since early childhood, she took up medical studies from her own will. [...] Alone in life, she does not know any lady next to her teachers and professors who can help her. [...] I think that if she might have one year experience in an American hospital, she might have a greater chance when back here, to enter the medical career with hope of success... which is much more difficult here for a woman than a man, especially if she has few worldly acquaintances. ${ }^{1}$

In a post-scriptum, Scouvart added that Pissoort's command of English was very good, as she had spent a whole year in England. Shaler carefully read Scouvart's letter, marked a few passages and responded in a reassuring way. He was no formal member of the selection committee, but promised to do everything he could to help her candidacy. According to his judgement, the information that Scouvart had given was very much in the candidate's favour. ${ }^{2}$ Shaler kept his promise. Pissoort received a scholarship and spent a year at Johns Hopkins University to specialize in Dermatology. She would not return to Belgium, but set up a practice in New York and become an American citizen.

While it is difficult to assess how much Scouvart's letter teaches us on the person of Pissoort, her letter does reveal something on the persona its author associated with a successful applicant. Besides the stress on behaviour, academic work, and language skills, Scouvart chose to point to the students' background as an orphan lacking a supporting network to underline Pissoort's independence and strong will. Her former teacher probably associated these qualities with the challenge of travelling to the United States and successfully performing a year of graduate study. Scouvart's letter also informs us about the working of the scholarship programme. In taking the initiative to write Shaler (who in his very informal response reminded Scouvart of his wife's wish to meet up soon), Scouvart unintentionally confirmed the importance of personal networks within the selection procedure. In addition, while she rightly pointed to the difficulties of women to gain access to male dominated professions, the correspondence reveals the space young female scientists seemed to have gained within this specific scholarship programme. Lastly, Scouvart's letter attests to a perceived asymmetry between Belgium and the 
United States in terms of openness to female academically trained professionals. It also attests to the belief that having been in the United States would enhance a woman's academic or professional opportunities afterwards in Belgium. These observations bring up larger questions. How was access to scientific travel regulated by this foundation, which functioned as a gatekeeper of transatlantic scientific travel? What qualities were needed to be selected as a fellow and in what ways were these qualities gendered? To what extent were travel experiences between Belgium and the United States shaped by the differing gendered academic cultures of both countries?

These questions are at the heart of this contribution on the CRB Educational Foundation's travel programme between Belgium and the United States during the interwar years. Our contribution focuses on women's participation in the programme during the interwar years and on the role of gender in the ways in which the foundation constructed and enacted ideals of being a good fellow. Our research does not only aim to enrich the scholarship on the history of scholarly personae by systematically integrating gender as a category of analysis. We also hope to broaden current historical research on personae by taking an institutional perspective. Scholarly personae, or broadly shared epistemic ideals and bodily repertoires that are associated with good scholarship and that have to be performed in order to be recognized as a scholar, are situated somewhere between the individual and the institutional, as Lorraine Daston and Otto Sibum stated in 2003 in a seminal article on "scientific persona" (which can be considered as a synonym of "scholarly persona", as long as it also includes the social sciences and humanities). ${ }^{3}$ Subsequent work on the historiographical potential of the concept has also pointed to the role of external pressures, institutional policies, and the regulative ideals of social groups such as patrons or science administrators in the formation of personae. ${ }^{4}$

Much empirical research on the history of scholarly personae focuses on individual or collective biographical trajectories of scholars. Studies on different types of scholars have analysed the negotiations which persona formation entails from the scholar's perspective, taking into account its social dimension informed by gender, class or ethnicity, disciplinary academic cultures or institutional pressures. ${ }^{5}$ Such studies, for sure, have also paid attention to scholarly personae as tools to understand (intra-)disciplinary identities or debates. In a similar vein, specific academic genres such as obituaries have been approached as battlegrounds 
for discussions on scholarly personae, taking a "middle-range position between the biographical and the social". 6 In our contribution, we will build upon this existing work, but we wish to add an extra layer to our understanding of persona formation by adopting an institutional perspective. So far, not many historians have explored this perspective, which looks at the way in which institutions such as funding agencies co-create personae by installing specific evaluative techniques and practices. ${ }^{7}$ In asking these questions, we come close to the study of today's evaluative cultures, a burgeoning field within the sociology of knowledge. This type of research, which reminds historians of the continuing importance of informal rules and criteria in assessment practices, is, however, not primarily interested in questions of persona formation. ${ }^{8}$

The advent of new academic funding agencies and the expansion of travel grants in the early twentieth century constitute an interesting possibility to study persona formation from such an institutional perspective. Young scientists had to meet new demands, which had to be "invented" by new institutions that could (or could choose not to) rely on older repertoires and images of scholarship. Applying for grants, being judged by selection committees, and reporting on the scientific results of a stay abroad: these are all instances of a new regime of accountability where ideals on scholarly life were enacted and exchanged, in a context of increasing transnational contacts. As in most of academic life, women held a marginal position in most of these institutions. This was certainly the case for the CRB Educational Foundation during the interwar years. In what follows, we start with a brief presentation of the organization and the position of women in its interwar history. We then focus on the foundation's policies of selection and surveillance of fellows. We subsequently turn to the fellows' own experiences and relate them to the foundation's construction of the persona of a fellow.

\section{From War Relief to Belgian AmERican EduCATIONAL Foundation}

Founded in 1920 as a bilateral project, the CRB Educational Foundation constitutes a textbook case of what Ludovic Tournès and Giles Scott-Smith in their recent study Global Exchanges, Scholarships and Transnational Circulations in the Modern World have called the second wave of scholarship programmes. ${ }^{9}$ The first wave, starting in the 1860 s, 
mainly consisted of unilateral, government-sponsored national, or empirebased travel programmes such as the Rhodes programme, paralleling the growing importance of strong and competing nation states and empires on the one hand and the professionalization of science on the other hand. The second wave, which arose in the 1910s, was of a quite different nature. In times of war, academic mobility came to be understood as a way to promote peace and international understanding. Paralleling a broader search for political and cultural infrastructures that allowed for international cooperation, the notions of reciprocity and exchange were introduced in scholarship programmes. Differently from before, the United States now started to play a prominent role in the field of scholarly exchange programmes, with philanthropic associations such as the Rockefeller Foundation and the Carnegie Corporation as main actors. These institutions invested in modelling post-war scientific practices and institutions in Western Europe on those in the United States, an effort that would be intensified after the Second World War. ${ }^{10}$

In the case of the CRB Educational Foundation, its wartime origins are obvious. After the First World War, the Commission for Relief in Belgium, that had provided humanitarian aid in occupied territory, disposed of a large amount of remaining funds. The two leaders of the relief programme, the later American President Herbert Hoover and the Belgian banker and entrepreneur Emile Francqui secured the remaining relief money and destined it for the development of higher education in Belgium. Two closely intertwined foundations were set up in 19201921, each of which reflected the ambitions of their respective chairman. Francqui led the Brussels-based University Foundation, that was specifically geared towards the internal improvement of Belgium's lagging higher education system. Hoover designed "his" foundation, which had offices in Brussels and New York, as "a memorial to American relief activities during the war" that would "build a permanent bridge of fine and high relationship" between Belgium and the United States. ${ }^{11} \mathrm{He}$ chose to work with "former CRB men" rather than academics. Hallam Tuck and Millard Shaler, engineers just as Hoover who had participated in war relief activities, led the Brussels office. Perrin Galpin, who had volunteered for the relief work in Belgium while an exchange student from Rhodes in Oxford, staffed the New York office. The wartime origins of the educational programme remained explicit in its name until 1938, when the organization was renamed Belgian American Educational Foundation. 
While the stated goal of the Foundation was to stimulate intellectual exchanges between Belgium and the United States, the transatlantic exchange of students and scholars soon constituted its core activity. Between 1920 and 1940, 687 persons crossed the Atlantic to study, teach, or perform research with the support of the foundation. ${ }^{12}$ Most of the fellows were young scientists, thus maximizing the possibility of long-term effects of the exchange experience. For every American fellow travelling to Belgium, on average two Belgian students went to the United States. This had not been the initial plan of the foundation, but as no graduate programmes of study comparable to the American ones existed at Belgian universities, American interest in the exchange programme soon became more limited than on the Belgian side. The imbalance in participation also paralleled the foundation's aim to rebuild Belgian academic life in a war-ruined country and its belief that American research universities with their much more extended staff and equipment, deserved emulation. The impact on Belgian academic life was indeed important. By 1938, fourteen per cent of the staff members at Belgian universities had been in the United States under the auspices of the foundation. ${ }^{13}$

The differences between American and Belgian universities and their respective reputations also reflected in the different distribution of academic disciplines within the exchange programme. Overall, during the interwar years, Belgians, more than Americans, travelled to specialize in medical and engineering sciences (52\% of Belgians versus $13 \%$ of Americans). The percentage of Americans coming to Belgium to study social sciences and humanities was much higher than among Belgians going abroad (66 versus 28\%). Only within the natural sciences, the share of students was almost equal. Belgians tended to travel to the United States to learn advanced techniques in medical and applied technical research, mostly in laboratories. Americans rather chose fields that were associated with "the old Continent", such as French literature, art, and history. They often also came to work in libraries and archives that preserved unique documents.

Less visible for contemporaries were the differences in participation by gender. The CRB Educational Foundation, which had an all-male executive management and board, did not include gender as a category in its own statistics. During the interwar years, about $20 \%$ of the American fellows were female. The women's colleges Radcliffe and Mount Holyoke were among those 15 institutions that sent five or more students to 
Belgium in the course of the interwar years. Among the Belgian exchange students and scholars, only 10\% were women, a percentage that included an all-female group of fifteen children's health teachers. ${ }^{14}$ For the Belgian case, this is significantly lower than women's share in university degrees in the same period, which corresponded to $17 \% .{ }^{15}$ Moreover, women were absent from the most prestigious category of visiting professor, and almost absent from the category of visiting scientist. Women were clearly overrepresented in some non-regular and less prestigious categories such as honorary fellowships where no money was involved (and one could for instance accompany a partner who was paid), more practically oriented special fellowships in domains such as library science and social work, and in the group of 15 children's health teachers. Patterns of female marginalization that have been described by Margaret Rossiter as "hierarchical discrimination", a marginalization that grows with the prestige of the functions or awards at stake, were clearly at work. ${ }^{16}$

At the same time, however, the Foundation was concerned with women's higher education. As early as 1921, Hoover had requested to examine the possibility to establish a women's college in Belgium. The project soon foundered, probably due to a lack of interest on the Belgian side, where separate university education for women was unknown. ${ }^{17}$ Hoover's idea to stimulate women's higher education in Belgium nevertheless materialized two years later, when the foundation funded the purchase of a building in Brussels for a non-academic, professional college for women. Between 1928 and 1932, however, two similar requests to fund professional schools for women were turned down, with reference to the fact that they did not contribute to the intellectual exchanges between Belgium and the United States. ${ }^{18}$ By that time, indeed, the foundation focused almost exclusively on its scholarship programme. While the participation of women was not a central concern in its policies, the question was not absent, in the first place in debates on what fellows should ideally look like and how to select them.

\section{Selecting the Ideal Fellow}

Finding the ideal fellow was a difficult task that aroused many doubts and discussions among the CRB officers. In 1930 Galpin reflected on that year's selection procedure posing the quintessential question: "Just what are we trying to accomplish? [...] Is it more valuable to work on intellectual relations of Belgium and the USA or on the bony structure 
of the embryonic ear?"19 Indeed, from its start in 1920, the exchange programme cherished a double aim: to stimulate scholarly education and research on the one hand, and to foster friendship between Belgium and the United States on the other hand. This meant that the ideal fellow was both an excellent student and a good ambassador. Financial support was preferably limited to those candidates who excelled in their specific domain of study and who prepared themselves for research, teaching, or other public service. While abroad, they had to act as good representatives of their country. Upon return, a lifelong task awaited them: Belgian fellows were for instance expected to "spread in Belgium the useful knowledge which they acquire in America in order to make use of their experience for the good of their country, and to develop close relations between Belgium and the United States". ${ }^{20}$

Contemporary fellowship programmes also tried to reconcile different, sometimes opposing, demands to their fellows. Similarly to the ambitions of the CRB, the Rhodes fellowship programme as well as the French Albert Kahn Around the World travel programme stressed the importance of mutual cultural understanding as an important long-term aim of the scholarships they awarded. The resulting sex and gender exigencies differed completely, however. The Rhodes programme did not accept women as applicants until as late as 1977 and framed its prospective fellows as "capable leaders". Since 1905, the Kahn programme had encouraged women to participate (albeit with the specific requirement that women had to travel in pairs of two). ${ }^{21}$ The Kahn programme recruited among (academically trained) secondary school teachers, which gave its aim of international understanding a different, less public, and less masculine meaning. When in the 1920s the International Federation for University Women set up its own, all-female fellowship programme, it explicitly chose to focus on strict scientific aims and criteria, and to exclude criteria related to personality or appearance. As Anna Cabanel has shown, this policy of promoting a disembodied type of scientific persona was part of a strategy aimed at overcoming long-standing bias against the alleged amateurism of female scholars. ${ }^{22}$

The CRB fellowship programme had no formal restrictions towards women. However, the language used by the foundation was consistently masculine-the category of "young men" was omnipresent in internal documents. The comprehensive profile of the ideal CRB fellow, including specific personality traits, also contained implicitly gendered connotations and thus shaped the possibilities for women. These connotations became 
manifest and sometimes explicit in the discussions on the admission of fellows. The need to make concrete decisions-which candidates qualified as suitable fellows?-resulted in ongoing discussions about the application procedure of the $\mathrm{CRB}$, often opposing the Belgian and the American branch of the organization.

A fellow's application started with a four-page questionnaire. Alongside factual queries on the candidate's education and the profession of her/his parents, the fellow was also expected to sketch her/his plans after completion of the stay abroad. The male gender of a normal CRB fellow was written into this questionnaire as well, through question 9 about the candidate's marital status and follow-up questions on the fellow's "wife". The fellow had to supplement the questionnaire with letters of recommendation. The writers of these letters tried to live up to the CRB's double expectations of scholarly excellence and ambassadorship. In 1921, for instance, an American candidate from the all-female liberal arts Smith College was praised as "a highly desirable representative of the American college woman in Belgium". 23 Former CRB visiting professor Henri Fredericq, professor of biochemistry in Liège, recommended his student Marcel Florkin because he possessed "to the highest degree all those qualities which arouse on the other side of the Atlantic a favorable opinion of the Belgian youth of our universities". 24

The recommendation letters also shed some light on the gendered nature of what was expected of a fellow. The overwhelming majority of male applicants were praised for their masculine virtues such as perseverance and strong will, as well as their professionalism. A 1937 recommendation letter on the medievalist Albert Lynd concluded in the following way: "He is (what would be called in the stock market) a good investment". 25 Female applicants were also qualified for their "excellent" or "interesting" academic results. At the same time, their social and moral qualities were highlighted more often. If, typically, in 1921 the engineer James Legrand received a recommendation from his Leuven professor Albert van Hecke for being "a very gifted boy, he works with method, regularity and already handles the English language very well", then in 1925 the biologist Lenette Rogers was presented, among other things, as "pleasing in appearance and manner". 26 She was also praised as "a good mixer", immediately followed by the conclusion: "So far as it is possible for a woman, she is the type that should accomplish much the sort of thing that you have mentioned as desirable in connection with these fellowships, through personal contact and impressions". ${ }^{27}$ 
Obviously, the recommendation letters were scripted, and to the frustration of the CRB, they did not always predict a fellow's success. What appeared to be good fellows on paper, might not meet the CRB's demands in practice. As Galpin wrote to Shaler in January 1924 about that year's selection of fellows: "The quality of the men is uneven and one or two Belgians who do not play the game in America may injure the Foundation and Belgium". ${ }^{28}$ Such disappointments led the CRB officials to adjust and rethink their selection procedure. This concern was certainly not unique to the CRB Educational Foundation. The Rockefeller Foundation for instance experimented in the same period with different types of selection procedures, ranging from local selection committees that assessed applications to relying exclusively on its own American officers who regularly visited laboratories, searching for young talented researchers who could be directly granted a travel fellowship, without applications. ${ }^{29}$ The CRB would work out different solutions for the American and the Belgian side of the selection procedure.

On the American side of the CRB, after two years of relying on the nomination of fellows by the participating universities, a fellowship Selection Committee consisting of professors and academic administrators was established. Throughout the interwar years, the composition of the committee would remain relatively stable. Occasionally, a Belgian visiting professor of the CRB Educational Foundation was added. As Belgian universities did not offer graduate study programmes, one of the main challenges of the American Selection Committee was to find candidates who were not merely looking for graduate course work, but who were also able to work independently. The yearly announcement soon included the requirement that a candidate "must be capable of independent study or research" and "must have definite plans for his proposed work in Belgium". ${ }^{30}$

In Belgium, selection took place in a much more complicated constellation. The task of selecting the fellows was attributed to the academic members of the Board of the University Foundation. In the early 1920s, the Selection Committee consisted of seven members: Francqui, the University Foundation's staff member Edouard Willems, a Brussels professor in medicine and university administrator, and the rectors of the four Belgian universities. They judged the applications of the CRB Educational Foundation and drew up a ranking of the candidates. Soon, however, the CRB officials became frustrated with the procedure, among others with what they perceived as particularist tendencies, each university 
(through its rector) trying to obtain as many fellowships as possible. ${ }^{31}$ That is why in 1923, in an attempt to exert more control over the rectors' decisions, Shaler was added to the Belgian selection committee. In the same year, Shaler and Tuck started conducting interviews with each candidate, "not especially in connection with his studies, but particularly with regard to his individuality and his knowledge of English". 32 These interviews resulted in frank assessments, sent to the Selection Committee. They combined criteria as divergent as research mentality, research subject, written and oral English skills, equilibrium between the universities and personality.

The stress on personality in interviews reveals a first tension between the CRB officials and the predominantly academic selection committees, concerning the ambassadorship of the fellows. According to Galpin, the Belgian university rectors gave too much weight to the academic results of the applicants and too little to "their character and personal presentability [sic] outside their purely academic attainments". 33 Similarly, in 1935, Shaler and Tuck voiced their concern about the American fellows who had been coming to Belgium: "We are not asking that candidates should be 'good mixers' but we do feel that they should be presentable and of the type we like to feel is representative of America”. And, remarkably, this specific quality was racialized: Shaler and Tuck related these observations to the fact that "we have been sending too many Jews". From New York, Galpin offered a reassurance that confirmed the rather explicit anti-Semitism: there would be only one Jew in next year's selection, even though, according to him, another candidate looked like one in his photograph. 34

A second issue leading to tension-fellows' disciplinary affiliationbrought gender issues to the surface. Unlike the Rockefeller Foundation, which strongly focused on the medical and social sciences in its European funding schemes, the CRB aspired to stimulate all disciplines. ${ }^{35}$ This ambition was hampered by the Brussels Selection Committee's strong preference for technical, medical and economic disciplines-disciplines geared towards the "rebuilding" of Belgium. ${ }^{36}$ Illustrative is the rejection of literature student Germaine Collette's request for a one-year extension of her stay at Stanford. Substantiating the committee's negative decision in a note to Tuck and Shaler, Edouard Willems referred to Francqui's wish to invest first in medicine and engineering, in the second place in business and only exceptionally in philosophy, philology, and law. The New York office was not amused. Galpin's answer pointed to the gendered 
effects of this policy: "We do not feel it would be wise to exclude any good men or women. [...] It also seemed likely that the new views of the Fondation Universitaire would tend to shut out Belgian women students from the benefits of the fellowship". 37 The fellowship was extended, but the University Foundation in the further discussion of the case did quite symptomatically not take up the issue of female access to fellowships.

A third issue was whether fellows could bring their families. At the start of the exchange programme, it seemed clear that both aims of the foundation-stimulating science and fostering cultural diplomacy-were best served by young single scholars (most frequently imagined as men). Unhindered by material and emotional concerns, they were expected to devote themselves completely to their work on the one hand, and to social contacts with the local community on the other hand. The age-old monastic ideal of scholarship seemed to match well with the new ideal of cultural exchange. As early as October 1921, opinions between Brussels and New York started to diverge. At that time, Shaler and Tuck in Brussels complained about the American fellows accompanied by their wives and (on three occasions) children. They wrote that these fellows "cannot find time not only to do justice to their university studies, but to get any advantage from social contact with Belgians. Being older men they are less easily influenced and moulded by such contact". ${ }^{38}$

Notwithstanding these concerns, the American side of the CRB would remain more family-friendly, also because advanced scholarships, and thus older fellows, became the norm on the American side of the programme. One effect of the decision to send families was that it allowed more chances for "collaborative couples" and thus for female scientists. ${ }^{39}$ In December 1929, for example, the American cytologist Thomas Weier wrote from Leuven: "Each day Mrs Weier goes with me to the laboratory to help in making microscopic preparations so that we may accomplish as much as possible in our short stay". ${ }^{40}$ When in 1926-1927 the botanist Raymond Bouillenne and his wife, the chemist Marie Bouillenne-Walrand, managed to both obtain a fellowship to work at the University of Pennsylvania, Raymond explicitly referred to the advantages of staying abroad together: "Accompanied by Mrs. Bouillenne, I am living in Philadelphia as I did in Belgium. I enter, as a matter of fact, more deeply into the modus vivendi of American people than would have been possible, had I been alone in hotels or in boarding houses. We call on and receive at home our Professors and their wives and also other friends". ${ }^{4}$ 
In sum, the American officials of the CRB-also those residing in Brussels-showed a greater concern to stimulate women as possible fellows during the application and admission procedure than the Belgian rectors or the officials at the University Foundation. Returning to the case of Elisabeth Pissoort with which this article started, it is noteworthy that it was Shaler who wrote to Willems at the University Foundation: "I very much hope that she obtains her scholarship and I am all the more desirous of this in view of the fact that she is the only woman candidate this year. She is from all points of view, as far as personality, intelligence and her ability to understand English is concerned, much superior to a considerable percentage of the young men whom I have examined". ${ }^{42}$ Pissoort received a scholarship indeed. To what extent did her and others' actual travel experiences match the CRB's expectation of the ideal fellow?

\section{EXPERIENCES OF EXCHANGE}

The CRB made great efforts to make its fellows' experience as rewarding as possible. First of all, this involved a lot of practical arrangements, such as booking the boat trip with Red Star Line between Antwerp and New York, helping out upon the fellows' arrival and, in particular for female students, finding housing. After the travel, the CRB offered facilities and support to combat loneliness and forge a group feeling among fellows. On the Belgian side, the CRB Club House, located next to the office and offering a quiet room for studying and a living room with a collection of American newspapers and periodicals, was meant to function as an attractive meeting place for both American and former Belgian fellows. Alongside a yearly Thanksgiving dinner organized by the Brussels office, people who were close to the foundation, among whom the wives of Tuck and Shaler, regularly organized weekend excursions, lunches, or afternoon teas, in some cases specifically for the female fellows. On the American side, Galpin was a tireless host during the fellows' first days in New York. $\mathrm{He}$ also encouraged the establishment of local CRB clubs, such as the one established in 1925 in Boston, to encourage meetings between Belgian and former American fellows.

Actively following fellows during their stay abroad was as much an expression of the CRB's genuine concern as it indicated the desire to control the fellows' good behaviour. To ensure that grantees would act as ideal fellows - that is: showing diligence and respectability-the CRB relied upon reports produced both by its own officials and other 
observers, such as professors at host institutions. The CRB did not feel inhibited to report upon a whole range of topics, including rather personal ones. Just one example were the political preferences of Caroline Bourland, a professor in Spanish literature from Smith College who came to Belgium to do research on the teaching of Spanish in sixteenth-century Flanders. In New York, Galpin was suspicious of Bourland's interest in the Spanish Civil War, and feared she might have fanatical loyalist, republican sympathies. Tuck and Shaler ensured him that, while Bourland was indeed open about her sympathies, she was a hard-working fellow who made an excellent impression everywhere. ${ }^{43}$ On another occasion, Galpin delved into the love life of the physicist Françoise Dony, who had become engaged with an American researcher. "Discreet inquiries" were made into the fiancé, who-to the foundation's relief-appeared to be a "very estimable gentleman". 44

The gendered and racialized expectations of candidates before they obtained fellowships remained present in the CRB's reports on actual fellows, albeit in varying degrees of explicitness. The chemist Lucy Pickett, for example, was judged negatively, not only because her French was unacceptably bad, but also because her personality was deemed too demanding and capricious. ${ }^{45}$ The Belgian student in social work, Georgette Furstenhoff who, in 1923, studied at Berkeley but had a negative experience with a traineeship, resulting in an early leave, was assessed in the following way by Galpin: "Her temperament injured her work. She was too sympathetic with the patients and wept over their troubles so that she was a nervous wreck at the end of that time and resigned from training. [...] She is very enthusiastic about America and is in good hands. She is, however, extremely independent"-independence obviously being a problematic character trait in the light of reigning gender expectations as well as the CRB's desire to control its fellows. ${ }^{46}$ The first African American recipient of CRB money was Francis Monroe Hammond, who received a Special Grant-in-Aid for his philosophy studies in Leuven. In a correspondence with the CRB, Hammond's examination results were judged upon by one of his Leuven professors as "maybe very good if one assesses them from the perspective of the capacities of his race. From an absolute point of view, they are barely satisfactory". ${ }^{47}$

If the CRB's reports on its fellows were stamped by its expectations, the same was true for another source of information employed by the foundation: the reports written by fellows themselves. This practice of self-reporting was installed by the CRB to learn about the fellows' 
needs, observe, and control their activities, and to prepare future fellows. Prospective fellows were encouraged to read reports as a first introduction to the country and the university they would visit. By consequence, later fellows reproduced the observations of their predecessors, inducing a uniformity in these texts, which was reinforced by the strict CRB instructions for writing them. Reports had to cover the study or research programme, the specificities of the host university and the broader experience abroad. During the first years, specific questions were added that testified of the (perceived) asymmetrical relation between both countries. Fellows were asked to suggest, based on their experience abroad, reforms in the academic system in their home country. Belgians also had to explain in what way they hoped to spread "the knowledge and experience of American methods and thought" after their return. ${ }^{48}$ American fellows, on the contrary, were encouraged to report on the "principal failures of University organization in Belgium". 49

The rather explicit directions of the CRB also took in existing images and clichés about the Old and the New World: American fellows had to group their observations regarding Belgium under the heading "old countries". No wonder, then, that the fellows' reports on their transatlantic exchange show a standardized experience-as is so often the case with travel writing. American fellows were amazed by the richness in historical treasures and cultural life, but also by the absence of modern living comfort, especially with regard to bathing and heating facilities. They were also struck by what was perceived as an old-fashioned observance of courtesy and etiquette and a hierarchical social stratification, which explained why "our American manners, camaraderie, and frankness are at times misunderstood". 50

Belgian reports on American academia were much in line with how the fellows had been prepared by the CRB. The facilities of the American universities, the modern equipment of laboratories, and well-organized library collections deeply impressed the exchange students. The way scientists behaved and interacted was also something of a culture shock for the Belgians, who were not used to the democratic and collaborative atmosphere in research laboratories and other research settings. Used as they were to an academic culture based on hierarchical relations between a maitre and his student, they were confronted with a different academic habitus. 51 "Those very friendly and fairly intimate relations between students and professors is one of the things we lack in our Belgian institutions, where many professors do not even know the names of the men 
and girls they teach", the linguist Irma De Jans observed after her stay at the University of Wisconsin in Madison. ${ }^{52}$ Exceptionally, the very positive renderings of the American teaching system were complemented by more sceptical notes. In 1923, Germaine Collette, a student of literature, reflected on the system in the following way, echoing broader anti-American cultural criticism: "On the whole I have the impression that the regular work imposed upon American students has a tendency to become mechanical. It is always very conscientious work but I am afraid it does not develop independence of taste and judgment as our system does". ${ }^{53}$ The reports written by fellows testify to an experience whereby students compared and contrasted their own and another nation's values and practices, confronted various preconceptions and national stereotypes, and articulated strengths and weaknesses of both countries. As has been argued by Whitney Walton in a study on educational travellers to and from the United States, this resulted in a revised sense of patriotism with an internationalist touch to it. ${ }^{54}$ This revised sense of patriotism was also one of the aims of the foundation. Students were expected to return to their country, to put what they had learned at the service of their nation and to function as ambassadors of their guest country. Judged by the vibrancy of its alumni association, the foundation seems to have been quite successful in attaining this goal, even when references to a shared war experience had quite soon lost their topical meaning for most fellows. ${ }^{5}$

While the fellows' experiences often seemed to conform to the carefully crafted expectations of their funder, there were also limits to the extent to which the experience of exchange matched the existing scripts. Real-life experience could, obviously, deviate from theory. The very first reports by American female fellows were so frank and outright negative about Belgium, that the CRB introduced a system of double-entry bookkeeping: one confidential, "with straight-forward criticism of the arrangements made with respect to American fellows", and one more public, "so as to create no social or administrative difficulties". ${ }^{56}$ American disappointments focused, firstly, on the Belgian academic system. "The quality of the teaching made it preferable to read than to attend lectures", a history student reported, while another fellow, a philosophy student, confessed that "on the whole the courses are neither as advanced nor as stimulating as I had hoped they might be". A bacteriologist observed that there was no check on class attendance, no discussions, no quizzes or interactions with the professor. Notes on the course from the previous year were 
readily obtainable. "Such a system cannot help but lower the general average standard of scholarship of the student body", she concluded, although she added that such a system, which placed the responsibility upon the initiative of the student, could bring out the best qualities in the exceptional student. A student in literature judged that the University of Brussels corresponded to a "distinctly poor undergraduate college in America", while a law student concluded in the following way: "After careful consideration, I fear I cannot mention any features of the Belgian system that I think could be advantageously applied by the universities with which I am familiar in the US". 57

Not only the Belgian academic system hindered American female fellows to embody the ideal CRB fellow in practice. The other side of the desired persona, the ambassadorship, was equally hard to enact because of the nature of Belgian social and academic life. Especially Leuven provided social hardship to female students, as was exemplified by the case of Anne Hart. As an advanced student in medieval literature in 1920-1921, she had been among the first cohort of 39 students to be admitted to the Catholic University of Leuven. Her observation was quite blunt: "Any participation in the student life at Louvain was made difficult by the attitude of the men toward the women and impossible by the special reglement governing the young women". Hart had only found out about the regulations a month after she had arrived. Contact between male and female students was virtually impossible. The presence of a nun at the meals of Hart and her Belgian and Russian fellow students in the dormitory was mandatory. Attendance at the early mass was compulsory. An innocent pastime such as "tea at a town pastry shop" was forbidden. ${ }^{58}$ In response to this situation, some women would decide, with the support of the CRB, to live in Brussels while studying in Leuven. This was the case for the aforementioned biologist Lenette Rogers, who in 1926 reported: "I find this arrangement infinitely more desirable than to live in Louvain [... ] where contacts are hard to make or maintain due to the great barriers between the men and women students. [...] Life at Louvain for a woman would be very dull indeed, and if she is alone, inadvisable". 59

Exclusion of female fellows was probably gravest in Leuven but it was also part of the experience of fellows in Ghent and Brussels, where female students were admitted since the 1880s. Their observations seem to confirm what Carol Dyhouse noticed on the British universities: the presence of a minority group of women frequently served to underline rather than to undermine the norms of the dominant masculine culture. ${ }^{60}$ 
The CRB fellows reported that it was difficult for women to make new acquaintances, to find housing, and that Belgian families were not inclined to host a female student on the same terms as they would a male student, without considering her as a lady-help. As Catherine Rich, the aforementioned student in bacteriology, wrote: "[Belgian society] places the American girl, especially, in a difficult position as few Belgians understand the freedom and independence that is part of her life". ${ }^{61}$ Some male CRB fellows also reported on the difficult position of women. They encouraged the CRB to make special efforts to support them. ${ }^{62}$ The fact that the CRB quarters in Brussels offered attractive lodgings for single men but not for women, certainly added to this feeling. In 1928, these quarters even remained empty, as the male fellows were all accompanied by their wives, the literary scholar Harriet Moriarty did not fail to notice. ${ }^{63}$

After some years, however, experiences of American CRB fellows would become more positive. Belgian academics had been repeatedly instructed by the CRB to take care of their American guests in a more personal way, and this seemed to be bearing fruit. In response to the disappointment of the first generations of fellows on the Belgian course offer, the American fellowships were transformed into research-oriented Advanced Fellowships. In many cases, the research stays not only resulted in several co-publications with the Belgian supervisor, but also in more long-standing research collaborations. ${ }^{64}$ With a view to their social integration, fellows staying in Brussels were encouraged to take their lunches in the Club of the University Foundation, where they could meet Belgian academic staff members. The weekly Sunday afternoon gatherings at the CRB house, where a piano and an open fire were installed, were clearly also helpful in countering loneliness. ${ }^{65}$

From the start of the exchange programme, Belgian female fellows offered a more positive reading of their American experience. There clearly was no need to start with confidential reports on the Belgian side. Although female fellows were not very explicit about it, the existence of female spaces such as women's colleges and women's dormitories, or networks such as the American Association of College Women seem to have been experienced positively. ${ }^{66}$ The issue of lodgings for female students was also taken care of by the host universities in ways that were certainly unknown to Belgian fellows. Apart from the peculiar case of Leuven and a small Maison des Etudiantes in Brussels, specific facilities for female students or researchers did not exist in Belgium. Belgian fellows hence had to be introduced into the system. In 1921, for instance, 
Galpin wrote the following to the CRB office in Brussels concerning the aforementioned Irma De Jans, who had experience as a language teacher and held a doctorate in Germanic philology: "Please understand that we were most strongly advised by several different persons at the University, including the Dean of Women to take the room in the French House for Miss De Jans. The Dean stated that she will be associated almost entirely with young women of her own maturity and she will have happier relations and form a juster picture of American womanhood by entering the French House, rather than obtaining a room outside". ${ }^{67}$ There was, however, exclusion in the United States as well. Marie-Thérèse Meuleman, medical doctor, learned that she could not become "House Officer" of the Boston Hospital, since there was no accommodation for women in the hospital. ${ }^{68}$ Marie-Thérèse Degard, another doctor who in 1937 hoped to acquire an additional degree in biology at the California Institute of Technology, was astonished to learn that this was not possible for women, although she had been able-partly thanks to interventions of the CRB - to do experimental work in several laboratories. This situation incited her to formulate some broader reflections on the situation of women at American universities: "In several universities women are not allowed. In others some professors are so hard on them that no women are able to go through to the doctor's degree. As this is well-known, the girls choose their university accordingly. I thought that only happened in Europe. I was disappointed to notice that sort of thing in the United States in which in general women's work is appreciated as much as men's work". 69

In spite of the obvious differences in opportunities for academic women between Belgium and the United States, Degard's explicit analysis was exceptional. The first generations of Belgian female fellows did not thematize gender in their reports. This was in line with the CRB's demands, which did not touch upon gendered differences. When addressing future fellows in the early reports, female fellows resorted to the "he"-form, reinforcing the implicit idea that a "normal" fellow was male. This was also in line with the existing strongly masculine and hierarchical Belgian academic culture, which did not encourage female fellows to reflect on gender issues. As in other European countries, access to higher education and to liberal professions had been on the agenda of the first organized women's movements since the 1880 s, but this had not resulted in a collective visibility or self-consciousness of female university 
students before the First World War. Rather, the women's reports testified of a concern not to attract attention as an individual-parallel to the broader tendency of many "first female students" since the late nineteenth century to keep a low profile.

The transatlantic exchange experience did however sometimes invoke awareness of gender issues. Both the aforementioned Marie BouillenneWalrand, who travelled with her husband, and the chemist Marguerite Van Hauwaert noticed how much more female-friendly the United States were, in terms of education, travel, and social relations. ${ }^{70}$ They could also have referred to the fact that American women had won the vote in 1920, while Belgian women merely had acquired municipal suffrage. Aimée Racine, a student in commercial law at the University of Wisconsin, was very outspoken about the benefits of American society: "Another thing which I like is the equality, both legal and social which exists between the sexes. There are almost unlimited opportunities for women. Practically no field of business or science is closed to them. [...] These conditions ought to be imitated in our country". ${ }^{71}$ Even though these types of comments were scarce among Belgians, the Belgian fellows mirrored in their reflections on gender relations the experiences of their American counterparts. For women, the persona that the CRB constructed seemed more within reach in the United States than in Belgium, both in its scholarly and its social aspects.

\section{CONCLUSION}

Private funding bodies such as the CRB Educational Foundation were relatively new scientific institutions in the interwar years. These funding agencies introduced new practices and demands to scientists, creating a scientific persona with obvious gendered connotations. In the case of the $\mathrm{CRB}$, institutional persona formation took place in both explicit and implicit ways. Explicitly, as the CRB consisted of a group of men who actively tried to define and negotiate what type of scientists they wanted to support: candidates who were at the start of their careers and combined a good academic record with strong social skills, "personality", and potential to act as an "ambassador".

More implicit were the effects of the CRB's procedures. To obtain the fellowships from the CRB, young scientists needed to master genres that were quite new in the interwar years, such as grant applications and progress reports in which the fellows answered to funding bodies. 
Such instances of contact between the CRB and its fellows-filing an application, giving an interview to the selection committee, or writing a report-were performances. At these moments, the (prospective) fellows had to answer to what the CRB exacted from them-they had to enact a fundable fellow. These performances were one of many aspects of scientific work, but the number of occasions in which funding bodies played a significant role would consistently increase in the course of the century, which underlines the relevance of the analysis we presented in this contribution. As becomes clear from the CRB's admission forms, reports, templates, and correspondence, these procedures were silently yet consistently framed in a gendered and racialized way: the default fellow was a white male.

The implicitly masculine character of the persona propagated by the $\mathrm{CRB}$ was reflected in the participation of female scientists: their numbers were lower than might have been expected based on their relative share in the student population. While the CRB officials acted with a certain awareness of the difficulties female candidates and fellows encountered, the CRB's Belgian partners did not share this awareness. All female candidates and fellows faced gendered inequalities and biases that existed both in the academic and the broader social world. Those inequalities were stronger in Belgium than in the United States. Belgian academia and the wider Belgian society proved a real hindrance to the possibility to enact the CRB's desired persona. For the Belgian fellows travelling to the United States, however, the experience of living in a country with more opportunities for women could function as an enabler to inscribe themselves into the CRB's persona of the scientist-ambassador, bringing home new visions on gender and society.

More generally, even though fellows were expected to inscribe themselves into a "sexless" discourse, the exchange experience itself proved a powerful incentive to challenge that discourse, as became clear from the reflections and comments on gender relations by both American and Belgian female fellows. This challenging could also take on other forms, especially for the Belgian fellows, who might choose, as Elisabeth Pissoort did, to deny their prescribed role in the rebuilding of post-war Belgium and decide to start a medical practice in New York. As our analysis has suggested, institutional persona formation should be considered as an increasingly important element of twentieth-century science and its gendered character, but the divergent appropriations by groups and individuals of institution-made personae were as much part of this history. 


\section{Notes}

1. BBAEF, 1.2.1: Alice Scouvart to Millard K. Shaler, February 9, 1923.

2. BBAEF, 1.2.1: Shaler to Scouvart, February 15, 1923.

3. Lorraine Daston and H. Otto Sibum, "Introduction: Scientific Personae and Their Histories," Science in Context 16, no. 1-2 (2003): 2.

4. Herman Paul, "What Is a Scholarly Persona? Ten Theses on Virtues, Skills and Desires," History and Theory 53 (October 2014): 367-369; Gadi Algazi, "Exemplum and Wundertier: Three Concepts of the Scholarly Persona," Low Countries Historical Review 131, no. 4 (2016): 27; Kirsti Niskanen, Mineke Bosch and Kaat Wils, "Scientific Personas in Theory and Practice-Ways of Creating Scientific, Scholarly, and Artistic Identities," Persona Studies 4, no. 1 (2018): 2.

5. See, for instance, Mineke Bosch, "Scholarly Personae and TwentiethCentury Historians: Explorations of a Concept," BMGN-Low Countries Historical Review 131, no. 4 (2016): 33-54.

6. Quotation Herman Paul, "Introduction: Scholarly Personae in the History of Orientalism, 1870-1930," in Scholarly Personae in the History of Orientalism, 1870-1930, eds. Christiaan Engberts and Herman Paul (Leiden/Boston: Brill, 2019), 6; See also Jeroen van Dongen and Herman Paul eds., Epistemic Virtues in the Sciences and Humanities (Cham: Springer, 2017).

7. Pieter Huistra and Kaat Wils, "Fit to Travel. The Exchange Programme of the Belgian American Educational Foundation: An Institutional Perspective on Scientific Persona Formation (1920-1940)," Low Countries Historical Review 131, no. 4 (2016): 112-134; Anna Cabanel, "'How Excellent... for a Woman'? The Fellowship Programme of the International Federation of University Women in the Interwar Period," Persona Studies 4, no. 1(2018): 88-102; Anna Cabanel, La fabrique d'une persona scientifique au féminin. The International Federation of University Women. Années 1920-années 1960 (unpublished PhD thesis, Universities of Leuven and Groningen, 2019).

8. See, for instance, the work in the wake of the influential study by Michèle Lamont, How Professors Think: Inside the Curious World of Academic Judgment (Cambridge, MA: Harvard University Press, 2009); Michael Ochsner, Sven E. Hug, and Hans-Dieter Daniel, eds. Research Assessment in the Humanities. Towards Criteria and Procedures (Cham: Springer, 2016).

9. Ludovic Tournès and Giles Scott-Smith, "Introduction: A World of Exchanges," in Global Exchanges, Scholarships and Transnational Circulations in the Modern World, eds. Ludovic Tournès and Giles Scott-Smith (New York and Oxford: Berghahn Books, 2018), 1-29. 
10. On the post-Second World War efforts, see for instance, John Krige, American Hegemony and the Postwar Reconstruction of Science in Europe (Cambridge, MA: MIT Press, 2006).

11. C.R.B. Educational Foundation, Inc. Annual Report for 1920 (New York, s.d.), 18, 19. Subsequent reference: Annual Report [year]. For a broader history of the origins and workings of the CRB Educational Foundation, see Liesbet Nys, Kenneth Bertrams and Kaat Wils, A Century of Transatlantic Scientific Exchange: The Belgian American Educational Foundation, 1920-2020 (Louvain: Leuven University Press, forthcoming).

12. All global numbers and percentages on the period 1920-1940 are based on Annual report 1939 and 1940, 9, 54-55, 72-74.

13. Annual Report 1937, 8.

14. This calculation is based on the list of individual fellows that can be found in Renaud Bardez, A Companion to the Study of the Belgian American Educational Foundation (Unpublished inventory, 2018), 18-46, 181-194.

15. Andrée Despy-Meyer, "Les étudiantes dans les universités belges de 1880 à 1941," Perspectives Universitaires 3, no. 1-2 (1986): 17-49.

16. Margaret W. Rossiter, Women Scientists in America, vol. 1: Struggles and Strategies to 1940 (Baltimore: Johns Hopkins University Press, 1984), 267-275.

17. Annual Report 1921 and 1922, 12; and BBAEF, 1.2.1: Memorandum of Discussion with Mr. Hoover, November 27, 1921.

18. Annual Report 1924, 6; BBAEF, 7.2.5 and 7.7.9.

19. Perrin C. Galpin to M.K. Shaler and W.H Tuck, February 14, 1930, quoted in Sara Coghe, Diplomaten en diploma's. De ambities van de Commission for Relief in Belgium Educational Foundation en de ervaringen van haar fellows aan de Katholieke Universiteit van Leuven (1920-1940) (Unpublished master thesis KU Leuven, 2018), 22.

20. Annual Report 1920, 33. See, for the American side, for instance, Annual Report 1935, 11.

21. Tamson Pietsch and Meng-Hsuan Chou, "The Politics of Scholarly Exchange: Taking the Long View on the Rhodes Scholarships," in Global Exchanges, Scholarships and Transnational Circulations in the Modern World, eds. Ludovic Tournès and Giles Scott-Smith (New York and Oxford: Berghahn Books, 2018), 41-42; Whitney Walton, Internationalism, National Identities, and Study Abroad: France and the United States, 1890-1970 (Stanford: Stanford University Press, 2010), 39-61.

22. Cabanel, "'How Excellent," 94-100.

23. BBAEF, 2.2.2: W.A. Nilson to Perrin C. Galpin, recommending Abba Bowen, April 11, 1921.

24. Henri Fredericq to Millard K. Shaler, February 2, 1928, quoted in Huistra and Wils, "'Fit to Travel,"” 128. 
25. BBAEF, 2.23.10: Lynn T. White to Perrin C. Galpin, recommending Albert Lynd, 15 November 1937.

26. "Un garçon fort bien doué, il travaille avec méthode, régularité et manie déjà fort bien la langue anglaise," quoted in Coghe, Diplomaten, 58; Alma G. Stokey to Perrin C. Galpin, recommending Lenette Rogers, February 20, 1925, quoted in Coghe, Diplomaten, 58.

27. BBAEF, 2.8.6: University of Wisconsin Professor to Perrin C. Galpin, recommending Lenette Rogers, 1925.

28. BBAEF, 7.33.1: Letter from Perrin C. Galpin to Millard K. Shaler, January $6,1924$.

29. See, for instance, on the German social sciences selection committee: Judith Syga-Dubois, "Managing Scientific Exchange in Interwar Germany," in Global Exchanges, Scholarships and Transnational Circulations in the Modern World, eds. Ludovic Tournès and Giles Scott-Smith (New York and Oxford: Berghahn Books, 2018), 113-126; on the policies of the Rockefellers' officers in France in the biomedical sciences: Ludovic Tournès, "Le réseau des boursiers Rockefeller et la recomposition des savoirs biomédicaux en France (1920-1970)," French Historical Studies 29, no. 1 (2016): 77-107.

30. Annual Report 1924, 29.

31. See for instance BBAEF, 1.8.1: Letter from Perrin C. Galpin to the University Foundation, September 15, 1924; and BBAEF, 7.14.5: Memorandum-Suggestions on Selection of CRB Belgian Fellows, NY office, January 17, 1928, and letter from Millard K. Shaler to Perrin C. Galpin, May 1, 1929.

32. BBAEF, 1.2.3: Letter from Millard K. Shaler to Perrin C. Galpin, January 24, 1923.

33. BBAEF, 7.33.1: Letter from Perrin C. Galpin to Millard K. Shaler, January $6,1924$.

34. Letter from William Hallam Tuck and Millard K. Shaler to C. Galpin, June 21, 1935 (first quotation); Letter from Perrin C. Galpin to William Hallam Tuck and Millard K. Shaler, June 7, 1935 (second quotation).

35. See for instance Ludovic Tournès, "La fondation Rockefeller et la construction d'une politique des sciences sociales en France (19181940)," Annales. Histoire, Sciences Sociales 63, no. 6 (2008): 1371-1402.

36. BBAEF, 1.2.3: Note de M. le Dr. Héger sur la modification éventuelle du règlement des bourses Américaines, n.d. [following upon the board meeting of the University Foundation of February 29, 1923].

37. BBAEF, 1.2.2: Letter from Edouard Willems to Millard K. Shaler and William Hallam Tuck, February 3, 1923, letter from Perrin C. Galpin to Shaler and Tuck, March 2, 1923 (quotation), and letter from Willems to Shaler and Tuck, March 5, 1923. 
38. BBAEF, 2.2.12: Letter from William Hallam Tuck and Millard K. Shaler to the office of the CRB Educational Foundation in New York, October 14,1921 .

39. On the concept and historical significance of 'collaborative couples,' see Annette Lykknes, Donald L. Opitz and Brigitte Van Tiggelen, eds. For Better or For Worse? Collaborative Couples in the Sciences (Basel: Birckhäuser, 2012).

40. BBAEF, 5.2: Preliminary report by Thomas Weier, dated December 1929.

41. BBAEF, 5.6: Preliminary report by Raymond Bouillenne, dated December 1926.

42. BBAEF, 1.4.22: Letter from Millard K. Shaler to Edouard Willems, March $21,1923$.

43. BBAEF, 2.23.2: Letter from Perrin C. Galpin to William Hallam Tuck and Millard K. Shaler, December 28, 1938, and letter from Tuck and Shaler to Galpin, January 13, 1939.

44. BBAEF, 1.21.8: Letters from Perrin C. Galpin to CRB Brussels office, April 19 and May 3, 1932.

45. BBAEF, 2.24.1: Letter from Jacques van der Belen to Perrin C. Galpin, December 27, 1939. Van der Belen joined Tuck and Shaler in the Brussels CRB office in 1936.

46. BBAEF, 7.33.1: Memorandum. Trips of Secretary to visit Belgian Fellows in West, New York, February 21, 1924.

47. BBAEF, 2.24.4: Letter from Léon Noël to Jacques van der Belen, January 20, 1939. On the Hammond case, see also Coghe, Diplomaten en diploma's, 63-65.

48. BBAEF, 1.2.1: Memorandum to all Belgian Fellows, 1921-1922. Final Reports.

49. BBAEF, 2.2.12: Questionnaire to serve as a guide to American fellows in preparing their reports, February 10, 1922.

50. Final report by Walter Marx, August 22, 1934, quoted by Coghe, Diplomaten en diploma's, 52-53.

51. See also Tournès, "Le réseau des boursiers Rockefeller," 91.

52. BBAEF, 5.4: Final report Irma De Jans, July 1922.

53. BBAEF, 5.4: Preliminary report Collette Germaine, dated June 1923.

54. Whitney Walton, "Internationalism, Travel Writing, and Franco-American Educational Travel, 1898-1939," in Crossing the Atlantic: Travel and Travel Writing in Modern Times, eds. Thomas Adam and Nils Roemer (Arlington: Texas University Press, 2011), 58.

55. As of 1929, the Belgian CRB alumni had their own journal Bulletin $d u$ Cercle des Alumni de la Fondation Universitaire.

56. BBAEF, 2.2.12: Questionnaire to serve as a guide to American fellows in preparing their reports, February 10, 1922. 
57. BBAEF, 2.1.14: Final report Amos Wilder, June 18, 1921 (first quotation); BBAEF, 2.2.10: Preliminary report Catherine Rich, December 17, 1921 (second quotation); BBAEF, 2.3.1: Preliminary report Florence Dixon, undated [January/February, 1922] (third quotation); BBAEF, 2.4.3: Preliminary report Clara Marburg, February 24, 1922 (fourth quotation); and BBAEF, 2.2.1: Preliminary report Eleanor Allen, December 11, 1921 (fifth quotation).

58. BBAEF, 2.1.5: Final report Anne B.G. Hart, July 1921.

59. BBAEF, 5.6: Preliminary report Lenette Rogers, December 1926.

60. Carol Dyhouse, "The British Federation of University Women and the Status of Women in Universities, 1907-1939," Women's History Review 4, no. 4 (1995): 470 .

61. BBAEF, 2.3.1: Preliminary report Florence Dixon, undated [January/February, 1922].

62. See for instance BBAEF, 5.2: Final report Leland Goodrich, April 5, 1925; Preliminary report Gray Cowan Boyce, January 1926.

63. BBAEF, 5.2: Preliminary report Harriet Moriarty, December 1928.

64. See, for instance, the final report of the pharmacologist Keith Grimson on his work in Ghent with Professor Corneille Heymans, September 2, 1939 (Stanford, Hoover Institution Library and Archives, CRB Educational Foundation Collection, Box 4, Folder 3).

65. See, for instance, BBAEF, 5.2: Preliminary report Mary Sherrill, December 3, 1928; Preliminary report Maurice Chazin, December 1929; Preliminary report Ruth Mary Reed, December 1929; Final report Ruth Mary Reed, August 1931.

66. BBAEF, 5.5: Preliminary report Elsa Claes, January 1925 and Final report Elsa Claes, 15 June 1925 (on how living in a dormitory had facilitated her social integration); BBAEF, 5.4: Final report Georgette Furstenhoff, June 1923 (on her regular participation in the meetings of the Association of College Women in San Francisco).

67. BBAEF, 1.3.7: Letter of Perrin Galpin to the CRB Office in Brussels, August 4, 1921 .

68. BBAEF, 1.5.15: Letter of Marie-Thérèse Meuleman to Perrin C. Galpin, April 20, 1924; Letter of Perrin C. Galpin to CRB Office Brussels, May 5,1924 .

69. BBAEF, 5.10: Final report Marie-Thérèse Degard, July 30, 1937.

70. BBAEF, 1.9.5: Preliminary report Marie Bouillenne-Walrand, August 21, 1927; BBAEF 5.2: Preliminary report Marguerite Van Hauwaert, February 1932.

71. BBAEF, 1.7.8: Preliminary report Aimée Racine, January 23, 1926. 


\section{BIBLIOGRAPHY}

\section{Archives}

Brussels, Archive of the Belgian American Educational Foundation (BBAEF).

Stanford, Hoover Institution Library and Archives, CRB Educational Foundation Collection.

\section{Published WORKS}

Bosch, Mineke. "Scholarly Personae and Twentieth-Century Historians: Explorations of a Concecpt." BMGN-Low Countries Historical Review 131, no. 4 (2016): 33-54.

Cabanel, Anna. “'How Excellent... for a Woman'? The Fellowship Programme of the International Federation of University Women in the Interwar Period." Persona Studies 4, no. 1 (2018): 88-102.

Cabanel, Anna. La fabrique d'une persona scientifique au féminin. The International Federation of University Women. Années 1920-années 1960. Unpublished $\mathrm{PhD}$ thesis, Universities of Leuven and Groningen, 2019.

Coghe, Sara. Diplomaten en diploma's. De ambities van de Commission for Relief in Belgium Educational Foundation en de ervaringen van haar fellows aan de Katholieke Universiteit van Leuven (1920-1940). Unpublished master thesis KU Leuven, 2018.

C.R.B. Educational Foundation, Inc. Annual Report (New York, s.d.) [19201940].

Daston, Lorraine and Sibum, H. Otto "Introduction: Scientific Personae and Their Histories." Science in Context 16, no. 1-2 (2003): 1-8.

Despy-Meyer, Andrée. "Les étudiantes dans les universités belges de 1880 à 1941." Perspectives Universitaires 3, no. 1-2 (1986): 17-49.

Dyhouse, Carol. "The British Federation of University Women and the Status of Women in Universities, 1907-1939." Women's History Review 4, no. 4 (1995): 465-485.

Gadi, Algazi. "Exemplum and Wundertier: Three Concepts of the Scholarly Persona." Low Countries Historical Review 131, no. 4 (2016): 8-32.

Huistra, Pieter and Wils, Kaat. "Fit to Travel. The Exchange Programme of the Belgian American Educational Foundation: An Institutional Perspective on Scientific Persona Formation (1920-1940)." Low Countries Historical Review 131, no. 4 (2016): 112-134.

Krige, John. American Hegemony and the Postwar Reconstruction of Science in Europe. Cambridge, MA: MIT Press, 2006.

Lamont, Michèle. How Professors Think: Inside the Curious World of Academic Judgment. Cambridge, MA: Harvard University Press, 2009. 
Lykknes, Annette, Opitz, Donald L., and Van Tiggelen, Brigitte eds. For Better or For Worse? Collaborative Couples in the Sciences, Basel: Birckhäuser, 2012.

Niskanen, Kirsti, Bosch, Mineke and Wils, Kaat. "Scientific Personas in Theory and Practice-Ways of Creating Scientific, Scholarly, and Artistic Identities." Persona Studies 4, no. 1 (2018): 1-5.

Nys, Liesbet, Bertrams, Kenneth and Wils, Kaat. A Century of Transatlantic Scientific Exchange. The Belgian American Educational Foundation, 1920-2020. Louvain: Leuven University Press, forthcoming.

Ochsner, Michael, Hug, Sven E., and Hans-Dieter Daniel eds. Research Assessment in the Humanities. Towards Criteria and Procedures. Cham: Springer, Cham, 2016.

Paul, Herman. "What Is a Scholarly Persona? Ten Theses on Virtues, Skills and Desires." History and Theory 53 (October 2014): 348-371.

Paul, Herman. "Introduction: Scholarly Personae in the History of Orientalism, 1870-1930." In Scholarly Personae in the History of Orientalism, 1870-1930, edited by Christiaan Engberts and Herman Paul, 1-16. Leiden/Boston: Brill, 2019.

Pietsch, Tamson and Chou, Meng-Hsuan. "The Politics of Scholarly Exchange. Taking the Long View on the Rhodes Scholarships." In Global Exchanges, Scholarships and Transnational Circulations in the Modern World, edited by Ludovic Tournès and Giles Scott-Smith 33-64. New York and Oxford: Berghahn Books, 2018.

Rossiter, Margaret W. Women Scientists in America, vol. 1: Struggles and Strategies to 1940. Baltimore: Johns Hopkins University Press, 1984.

Syga-Dubois, Judith. "Managing Scientific Exchange in Interwar Germany." In Global Exchanges, Scholarships and Transnational Circulations in the Modern World, edited by Ludovic Tournès and Giles Scott-Smith, 113-126. New York and Oxford: Berghahn Books, 2018.

Tournès, Ludovic. "La fondation Rockefeller et la construction d'une politique des sciences sociales en France (1918-1940)." Annales. Histoire, Sciences Sociales 63, no. 6 (2008): 1371-1402.

Tournès, Ludovic. "Le réseau des boursiers Rockefeller et la recomposition des savoirs biomédicaux en France (1920-1970)." French Historical Studies 29, no. 1 (2016): 77-107.

Tournès, Ludovic and Scott-Smith, Giles. "Introduction. A World of Exchanges." In Global Exchanges, Scholarships and Transnational Circulations in the Modern World, edited by Ludovic Tournès and Giles Scott-Smith, 1-29. New York and Oxford: Berghahn Books, 2018.

Van Dongen, Jeroen and Paul, Herman eds. Epistemic Virtues in the Sciences and Humanities. Cham: Springer, 2017. 
Walton, Whitney. Internationalism, National Identities, and Study Abroad: France and the United States, 1890-1970. Stanford: Stanford University Press, 2010.

Walton, Whitney. "Internationalism, Travel Writing, and Franco-American Educational Travel, 1898-1939." In Crossing the Atlantic: Travel and Travel Writing in Modern Times, edited by Thomas Adam and Nils Roemer, 50-78. Arlington: Texas University Press, 2011. 